\title{
COST EFFECTIVE NITROGEN REMOVAL - NOVEL CONTROL STRATEGIES
}

\author{
ALAM NAWAZ, ${ }^{1}$ AMARPREET SINGH ARORA, ${ }^{2}$ CHOA MUN YUN,${ }^{4}$ HWANCHUL $\mathrm{CHO}^{5}$ \& \\ MOONYONG LEE ${ }^{3, *}$ \\ 1,2,3 School of Chemical Engineering, Yeungnam University, Gyeongsan, South Korea. \\ ${ }^{4}$ Sherpa Space Inc., Daejeon 34051, Republic of Korea. \\ ${ }^{5}$ Doosan Heavy Industries \& Construction, Yongin 16858, Republic of Korea.
}

\begin{abstract}
The anammox process, used to remove nitrogen from wastewaters is conside red a promising approach due to its advantages over traditional processes. The current study emphasizes on the cost effective nitrogen removal from the sidestream effluent of anaerobic digester with partial nitration (PN) and anaerobic ammonium oxidation (anammox) process for the municipal wastewater treatment plant. The main objective of this study was to model a cost effective strategy for setting up a lab-scale sequencing batch reactor (SBR) by using activated sludge model (ASM) process equations with applying novel control strategies (NCS) for improving nitrogen-removal efficiency (NRE). An average rate of removal $80 \%$ was obtained during the period of its operation. NCS (intermittent aeration, alteration in the cycle length, etc) were introduced to optimize the operating cost. The overall system contributes to lowering in the greenhouse gas emissions by minimizing the use of energy (60-65\%) and hence supporting the WHO mission of achieving sustainable development goals. Results further indicate the future possibility of escalating the lab-scale to full-scale applications.
\end{abstract}

Keywords: Anammox, Control Strategy, NRE, Operating Cost, PN, WHO Mission.

\section{INTRODUCTION}

Finding a cost-effective way in treating wastewater process selection is very essential with a rapid growing field of wastewater treatment plants for lab-scale and full-scale applications. Currently, two sequential biological processes (nitrification by autotrophic and denitrification by heterotrophic bacteria) are used concurrently in wastewater treatment plant for removal of nitrogen [1].

$$
\begin{gathered}
\mathrm{NH}_{4}+1.32 \mathrm{NO}_{2}^{-}+0.066 \mathrm{HCO}_{3}^{-}+0.13 \mathrm{H}^{+} \rightarrow 1.02 \mathrm{~N}_{2}+0.26 \mathrm{NO}_{3}^{-} \\
+0.066 \mathrm{CH}_{2} \mathrm{O}_{0.5} \mathrm{~N}_{0.15}+2.03 \mathrm{H}_{2} \mathrm{O}
\end{gathered}
$$

The anammox process, first came in existence in 1986 through a study conducted on a fluidized bed reactor (an anaerobic denitrifying bacteria) [2]. It also occurred in marine sediments and anoxic column as reported in the literature [3, 4].

In 1990s era, anammox mechanism in eqn (1) was observed, where nitrogen gas as an electron accepter under anaerobic conditions with nitrite [5] was directly converted by $\mathrm{NH}_{4}^{+}$ and offered best opportunities for wastewater engineers [1] in the wastewater field.

High sensitive anammox process is inhibited by many factors (high substrate concentrations of ammonia, nitrite, organic matter, heavy metals etc.) and variations in operating conditions (Dissolved oxygen (DO), pH, Temperature, etc.). Most of the studies, applied different control strategies in biological nutrient removal to achieve the desired result. DO seems to be an important inhibitor that has a reverse effect on anammox bacteria $[1,6]$. One of the case study simulated, model predictive control (MPC) for controlling DO concentration [7]. Another study examined the enrichment of anammox by $\mathrm{pH}$ range between 7.0 and7.5 [8] and its 
effect on nitrogen removal [9]. Temperature is also key parameter that affects the microbial structure, in achieving the high performance [10], an optimal temperature $\left(35^{\circ} \mathrm{C}-40^{\circ} \mathrm{C}\right)[11] \S$ for the anammox bacteria was required. The negative impact by nitrite substrate at high concentrations was also observed on the Anammox bacteria [12].

It is a challenging task to achieve a higher nitrogen removal with minimum operating cost under aforementioned control strategies reported by different studies. Thus, this paper emphasizes cost effective NCS incorporating optimum boundaries which are applied into the SBR model. With these boundaries, there is a flexibility to change the lower and upper bound in achieving minimum operational cost, targeting highest nutrient removal in accordance with the world health organization (WHO) standards. After defining the boundaries, SBR model was developed, and incorporated with optimum control strategies and ASM process equations.

\section{MATERIALS AND METHODS}

\subsection{SBR process and operation}

Lab-scale SBR tank with 63L volume was operated and controlled by user-friendly CIMON based SCADA program for 300 days. Twenty litres of digester effluent was treated in the SBR tank for removing the nutrients and temperature range was maintained between $33 \pm 2{ }^{\circ} \mathrm{C}$ by placing the entire system inside an incubator. An Equalization (EQ) tank with 37.5L volume was used to store influent wastewater coming from the digestion liquor effluent. Figure 1 shows schematic diagram of lab-scale SBR system.

Table 1 describe the entire process operation before and after applying NCS of the SBR system, in which $6 \mathrm{~h}$ cycle (i.e. 4 cycles/day) were operated for treating $20 \mathrm{~L}$ after applied NCS instead of $8 \mathrm{~h}$ cycle of process operation. Each complete cycle consist sub-cycles to maximize the efficiency and minimize the energy consumption. The SBR volumetric exchange rate [13] was $36 \%$.

\subsection{Model development}

The SBR Model is developed by using activated sludge model (ASM) [14-16] and their process equations under the MATLAB R2018a environment. This model is validated with

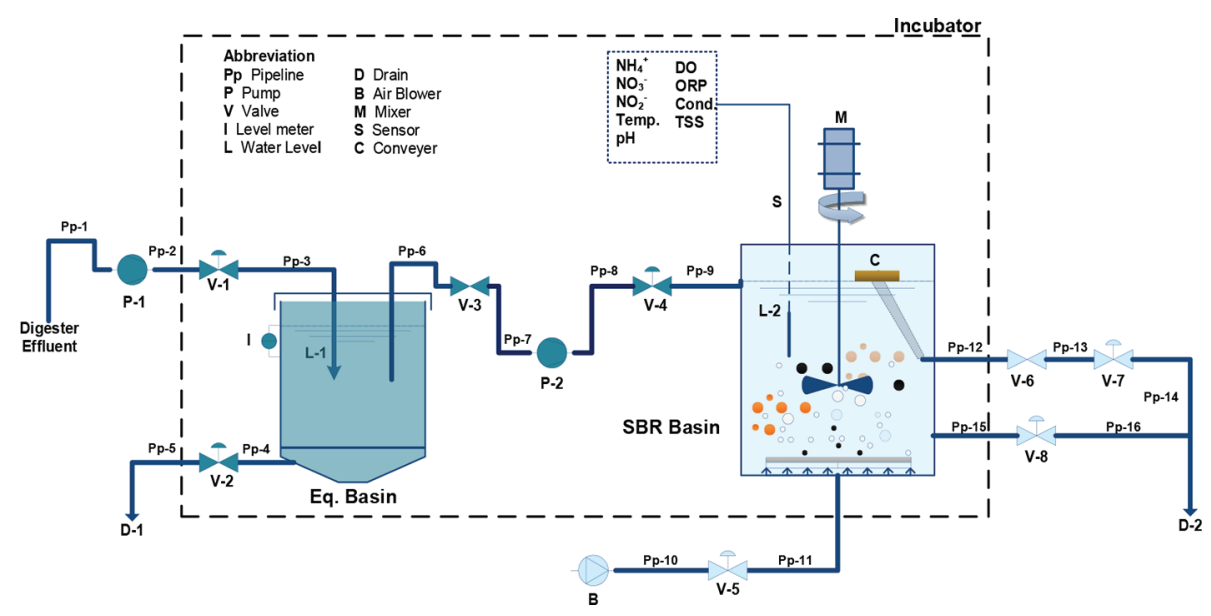

Figure 1: Lab-scale SBR process flow diagram. 
Table 1: Operational phases of the Anammox SBR cycle before and after applying NCS.

\begin{tabular}{lcccc}
\hline & \multicolumn{2}{c}{ Before NCS } & \multicolumn{2}{c}{ After NCS } \\
Phases & $\begin{array}{c}\text { Processing } \\
\text { Time (min) }\end{array}$ & $\begin{array}{c}\text { Total time } \\
(\mathbf{m i n})\end{array}$ & $\begin{array}{c}\text { Processing } \\
\text { Time (min) }\end{array}$ & $\begin{array}{c}\text { Total time } \\
(\mathbf{m i n})\end{array}$ \\
\hline Filling & 15 & 15 & 10 & 10 \\
Anoxic (mixing) & 215 & 230 & 150 & 160 \\
Aerobic & 200 & 430 & 150 & 310 \\
Settling & 50 & 480 & 50 & 360 \\
\hline
\end{tabular}

operational data before implementing in the lab-scale system. In order to overcome the below mentioned problems, these assumptions/problems were made during the development of SBR model validation.

1. It has a risk of inaccurate data due to the online sensor fault and error.

2. The online monitoring $[17,18]$ value under operating condition of the sequencing batch reactor (SBR) is unreliable as the value is calculated under various mutable conditions.

3. The control of the predetermined cycle, cost saving and an optimum operation effect is insignificant.

4. There is a lack of response to uncertain raw water and environmental conditions.

5. Operating \& maintenance minimization is not considered as an important variable for satisfaction of effluent condition.

\subsection{Constraint handling}

To overcome the above-mentioned assumptions and based on control strategies in this current study, the following knowledge-based constraints (incorporated with SBR model) are most essential to handle in order to achieve desired nutrient removal output before applying NCS.

The objective of current study was to optimize the operating cost with desired removal efficiency of nutrient.

$$
\begin{aligned}
& \text { Minimize } f(C)=\text { Min. }\left(\sum_{i=1}^{n} e_{i}\right) \\
& \text { where, } i=1,2,3, \ldots n
\end{aligned}
$$

where e is energy consumption constant and $f(C)$ is the function of cost, which is calculated by processing time of units $\left(u_{\text {blower }}, u_{\text {mixer }}\right.$, and $u_{\text {pump }}$, etc.).

$$
e_{i}=\left(u_{\text {blower }}+u_{\text {mixer }}+u_{\text {pump }}\right)
$$

Subject to

$$
\begin{aligned}
& C_{\mathrm{NO}_{2}}<121,(\text { Aeration phase }), \\
& C_{\mathrm{NO}_{2}-\mathrm{N} / \mathrm{NH}_{4}-\mathrm{N}}<1.3,(\text { Filling phase })
\end{aligned}
$$




$$
7.3 \leq p H \leq 7.5
$$

where $\mathrm{C}$ is the key variable bounded as,

$$
C_{j}^{l b} \leq C_{j} \leq C_{j}^{u b}, \text { where } j=1,2,3, \ldots, n
$$

DO and ratio of $\mathrm{NO}_{2}-\mathrm{N}: \mathrm{NH}_{4}-\mathrm{N}$ in ranges between as mentioned below,

$$
\begin{aligned}
& 0.2<C_{D O}<0.8,(\text { at Aeration phase }), \\
& 0.8<C_{\mathrm{NO}_{2}-\mathrm{N} / \mathrm{NH}_{4}-\mathrm{N}}<1.6,(\text { at Anoxic } \text { phase })
\end{aligned}
$$

\subsection{Experiment and online reading}

Standard methods were performed to analyze all physio-chemical parameters. HACH company equipment is used for analytical measurement of DO, ORP, $p H$, TSS etc. As shown in Fig. 1, all probes such as $\mathrm{DO}, \mathrm{pH}, \mathrm{NH}_{4}^{+}, \mathrm{NO}_{2}^{-}$, conductivity, ORP, and temperature $\left(33 \pm 2{ }^{\circ} \mathrm{C}\right.$ maintained by incubator) were dipped into the SBR reactor for recording the data. During these experimental and online measurement procedures, quality standards were ensured.

\subsection{Control strategies for important parameters}

The lab-scale SBR was operated continuously for 300 days with various changes being introduced in order to acquire the optimum nutrient removal efficiency. The important parameters are outlined as:

1. Feed condition; defining the feed, can reduce the cost. Since EQ tanks conditions are different to SBR reactor except temperature, thus it is required to measure the EQ influent conditions,

2. Length of cycle; in start-up phase, cycle time $12 \mathrm{~h}$ with hydraulic retention time (HRT) of $24 \mathrm{~h}$ was used. Then it was reduced to $6 \mathrm{~h}$ with HRT of $12 \mathrm{~h}$ at specific removal efficiency. A complete cycle was divided into several cycles with 10-30 min/sub-cycle,

3. Nitrogen loading; the influent-N concentration varied from 140 to $300 \mathrm{mg}-\mathrm{N} / \mathrm{L}$ was optimized by cycle time,

4. Aeration time; it is crucial parameter directly associated with operational cost, which is optimized by applying intermittent aeration to sub-cycle of one complete cycle during the SBR operation,

5. Maintain Anammox bacteria; it is also one of the important parameter by which we can also minimize the aeration. A physical microorganism separator (PMS) was used to maintain the anammox granules and recycle into the SBR tank.

6. Filling time; it is controlled by maintaining the volume minimum $10 \%$ or more in the SBR reactor.

7. Continuous mixing; it is ensured that continuous mixing was performed to minimize the aeration and increase the ammonia-oxidizing bacteria (AOB) activity.

8. Immediate aeration after mixing; after mixing operation of sub cycle, immediate aeration was performed.

A strategic procedure was adopted for successfully applying cost effective NCS in current study to anammox process, as illustrated in the Fig. 2. In order to evaluate its effectiveness, 


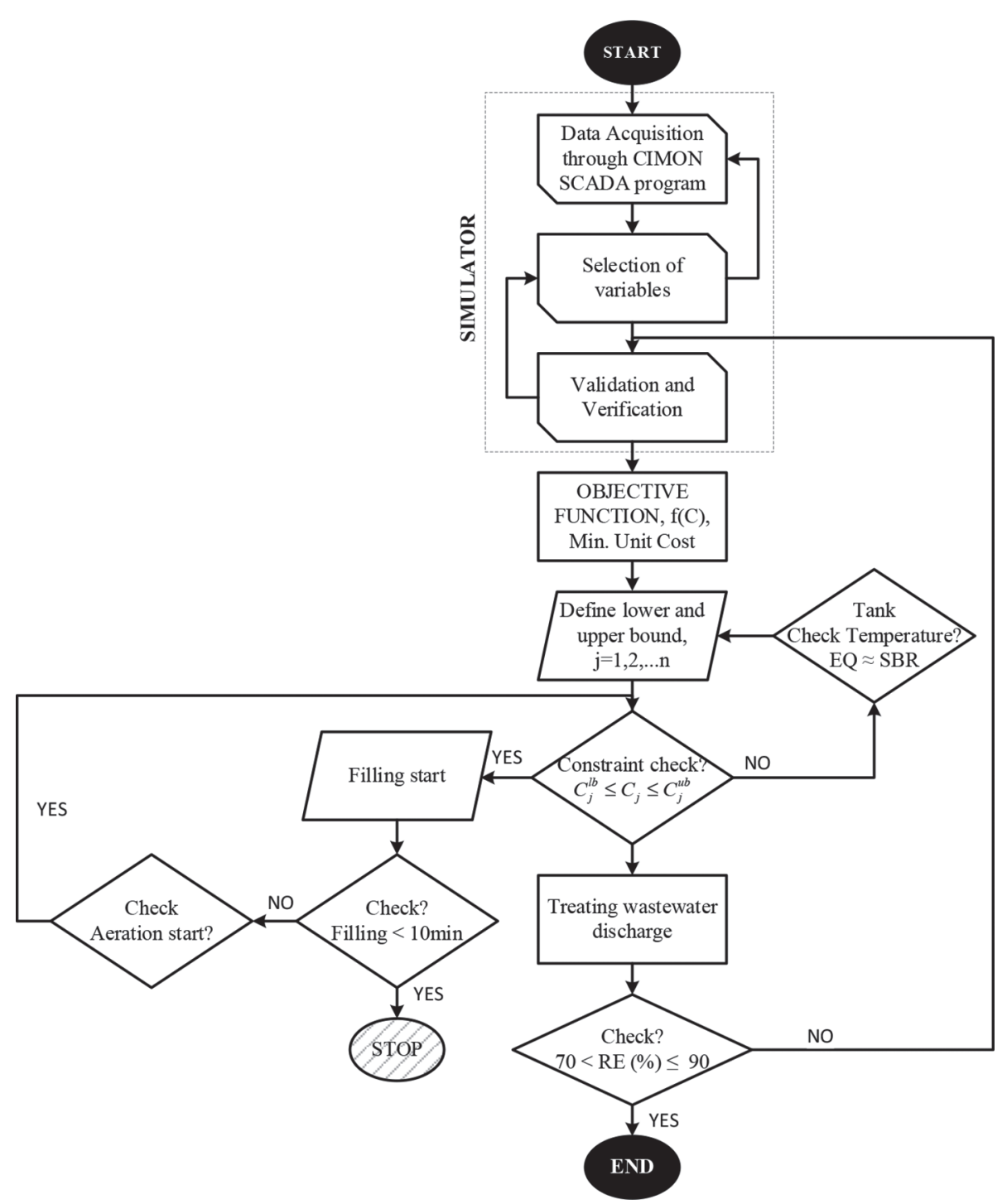

Figure 2: Schematic diagram of control strategies.

Fig. 2 procedure was implemented to one batch process that consisted of a total of three sub-cycles in complete one cycle. Besides this, it was also ensured, that the constraints are satisfied before discharging the treated wastewater. Until the desired removal rate (\%) is not satisfied under these conditions, system again validates the SBR model.

\subsection{WHO sustainable goal achieved}

The results shows that this work is in alignment with the sustainable development goals number 6 [19] and, 7 [20] out of the total 17 of WHO mission, which ensures the clean water and clean energy standard by obtaining the following as given below. 
- Biogas utilization,

- Minimization of energy consumption by reduced aeration time,

- Removing the pollution from wastewater through nutrient removal.

\section{RESULTS AND DISCUSSION}

\subsection{Digester liquor characteristics}

The lab-scale SBR unit research and development by Yeungnam University, Daegu, South Korea and Doosan Heavy Industrial Ltd, Doosan, South Korea was operated for 300 days. During the period from the start-up phase until obtaining the desired efficiency of nitrogen removal, numerous changes were incorporated to optimize the system. The overall composition of the digester effluent received as the influent in the EQ tank for treatment and the quality of the drained effluent in SBR tank before and after NCS are listed in Table 2.

\subsection{Achieving rate of removal}

In Fig. 3, during the start-up phase of lab-scale process before applying NCS, about 87\% nutrient removal rate was obtained as shown due to added enriched anammox granules. After start-up, immediately $7 \%$ decrease in the removal rate was observed during the period of 20-75 days due to time taken by anammox, AOBs, NOBs, and heterotrophic bacteria for getting acclimatized in SBR reactor conditions. After 75 days, the anammox system has been stabilized with 5\% decrease in the nutrient removal efficiency. During the period of 78-300 days, an average $\mathrm{NH}_{4}-\mathrm{N}$ removal rate of SBR reactor was $74 \pm 2 \%$.

In comparison it can be seen in the Fig. 4 after applying NCS, about approximate one year of period, the anammox process under the normal condition with applying optimum control strategies using SBR model run successfully and acquired the optimum removal rate $80 \%$.

Table 2: Digester liquor characteristics of before and after $\mathrm{PN}$-anammox treatment.

\begin{tabular}{lccccc}
\hline \multirow{2}{*}{ Parameter } & \multirow{2}{*}{ Unit } & \multicolumn{2}{c}{ Before NCS } & \multicolumn{2}{c}{ After NCS } \\
& & Influent & Effluent & Influent & Effluent \\
\hline Temperature & ${ }^{\circ} \mathrm{C}$ & $33.6 \pm 0.5$ & $33.8 \pm 0.5$ & $33.6 \pm 0.6$ & $33.8 \pm 0.6$ \\
$\mathrm{pH}$ & - & $7.7 \pm 0.24$ & $7.37 \pm 0.23$ & $7.78 \pm 0.21$ & $7.4 \pm 0.2$ \\
Conductivity & $\mu \mathrm{S} / \mathrm{cm}$ & $3323.7 \pm 780.6$ & $3155 \pm 854$ & $3774 \pm 574$ & $3582.6 \pm 639$ \\
Ammonium & $\mathrm{mg} / \mathrm{L}$ & $183 \pm 34$ & $45.9 \pm 12$ & $190.5 \pm 24.8$ & $47 \pm 8$ \\
Nitrite & $\mathrm{mg} / \mathrm{L}$ & $22.9 \pm 36$ & $15 \pm 36$ & $38.3 \pm 45.4$ & $31 \pm 45.9$ \\
Nitrate & $\mathrm{mg} / \mathrm{L}$ & $17.8 \pm 5$ & $16.9 \pm 9$ & $16.9 \pm 4.6$ & $13.7 \pm 7.6$ \\
DO & $\mathrm{mg} / \mathrm{L}$ & $0.15 \pm 0.06$ & $0.17 \pm 0.16$ & $0.16 \pm 0.07$ & $0.19 \pm 0.18$ \\
TSS & $\mathrm{mg} / \mathrm{L}$ & $3.4 \pm 1$ & $1.9 \pm 1.6$ & $3.11 \pm 1.3$ & $1.9 \pm 1.6$ \\
ORP & $\mathrm{mV}$ & $-95.8 \pm 139.4$ & $-113 \pm 151$ & $-100.7 \pm 138$ & $-123 \pm 154$ \\
\hline
\end{tabular}




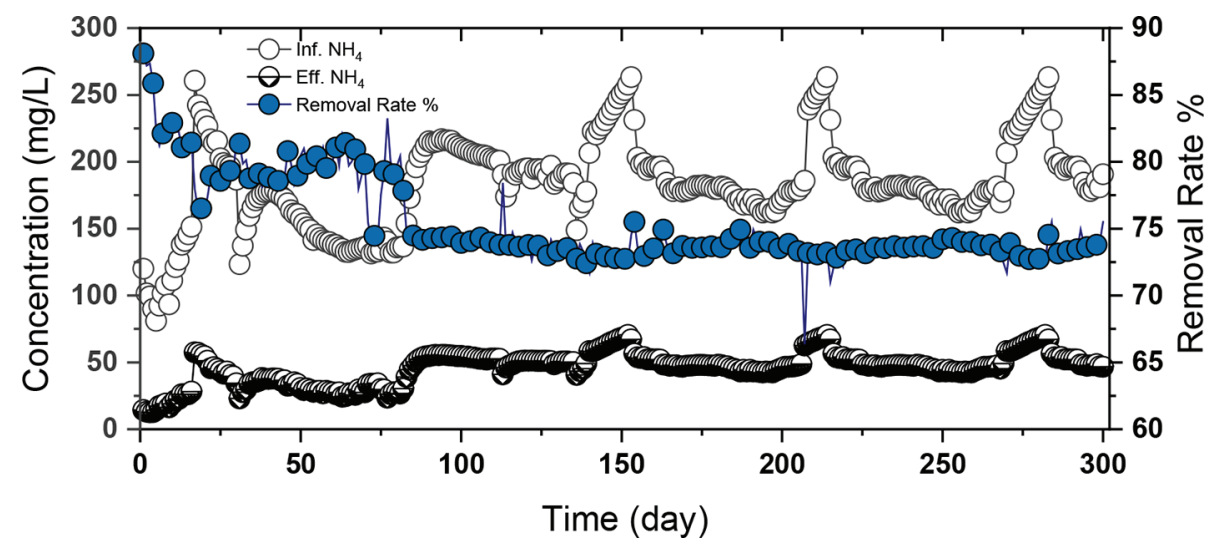

Figure 3: Removal rate (\%) over the entire period of operation along with influent and effluent $\mathrm{NH}_{4}-\mathrm{N}$ concentrations.

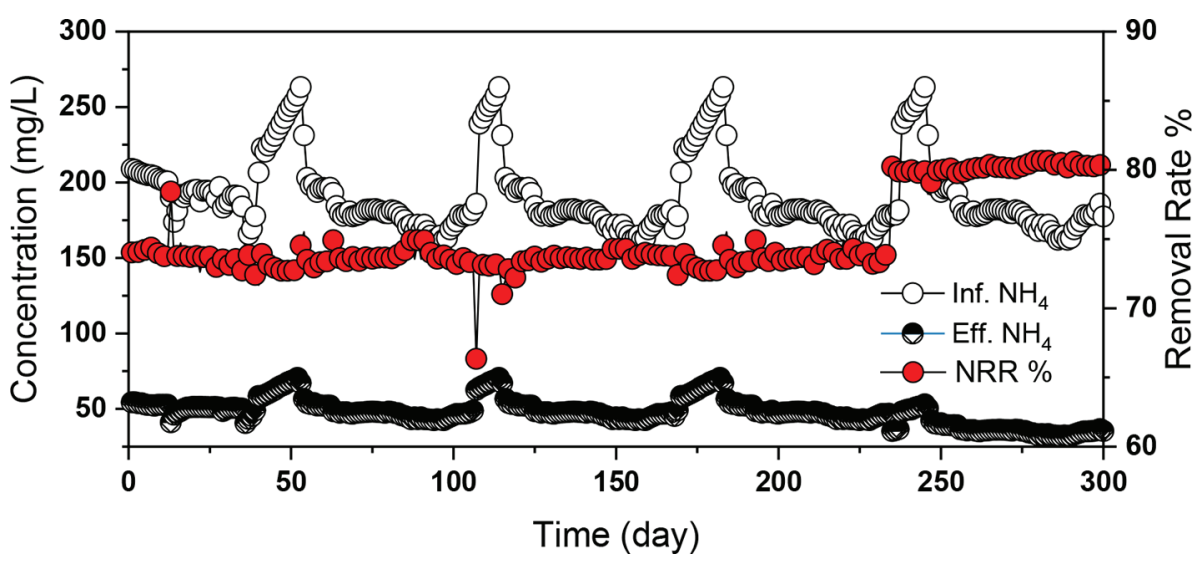

Figure 4: Removal rate (\%) over the entire period of operation along with influent and effluent $\mathrm{NH}_{4}-\mathrm{N}$ concentrations after applying NCS.

\subsection{Minimized operating cost}

Operational cost-relatively increase with increase in the availability of processes equipment. One of the control strategy, an intermittent aeration, mixing, and filling were used to minimize the operating cost into the sub-cycles of $6 \mathrm{~h}$ complete cycle. Mainly, it was ensured that the aeration starts immediately after mixing, by which low aeration is required during the anammox system run over 300 days.

\subsection{Cost estimation and sustainable goals}

The anammox system run under normal conditions, shows $60 \%$ of lower operational cost than cost of conventional BNR process. In estimation of the unit processing cost below mentioned eqns (7)-(9) were used. 


$$
\begin{gathered}
e_{i}(/ \text { day })=(K W / \text { efficiency }) * h r \\
P_{c}(\$ / \text { day })=e_{i} * \cos t(\$) \\
T_{c}(\$ / Y r)=\left(e_{\text {blower }}+e_{\text {mixer }}+e_{\text {pump }}\right)_{\cos t} * 365
\end{gathered}
$$

where $e_{i}$ is combined consumption energy of blower, mixer, and pump units, which is calculated by ratio of power and their efficiency in terms of per day. Term, $P_{c}$ and $T_{c}$ are representing processing cost per day and total annual cost per day, respectively. In this study, estimated processing cost is $\$ 3474.3 /$ year with rate of $1 \$ / \mathrm{kWh}$ energy for lab-scale anammox process and saved $62.5 \%$ energy consumption in comparison with conventional BNR process. In addition to this energy saving biogas is also obtained in terms of by-product which can thus be served as an alternative source of energy.

\section{CONCLUDING REMARK AND FUTURE ASPECTS}

This study encountered numerous changes during the application of NCS with constraints at lab-scale Anammox process in order to acquire a cost-efficient rate of nutrient removal. The estimated operational cost is about $\$ 3474.3 /$ year with $62.5 \%$ of energy consumption savings in comparison with conventional BNR process. In addition, by-product biogas could also be used in different purposes as energy source.

The outcome of this study would be useful to wastewater engineers in adopting these NCS for full-scale applications.

\section{ACKNOWLEDGEMENTS}

This work was supported by the 2018 Yeungnam University Research Grant. This work was also supported by Doosan Heavy Industries and Construction grant (Y16031) and by Priority Research Centers Program through the National Research Foundation of Korea (NRF) funded by the Ministry of Education (2014R1A6A1031189).

\section{REFERENCES}

[1] Jetten, M.S., Strous, M., van de Pas-Schoonen, K.T., Schalk, J., van Dongen, U.G., van de Graaf, A.A., Logemann, S., Muyzer, G., van Loosdrecht, M.C. \& Kuenen, J.G., The anaerobic oxidation of ammonium. FEMS Microbiology Reviews, 22(5), pp. 421-437, 1998.

[2] Mulder, A., van de Graaf, A.A., Robertson, L.A. \& Kuenen, J.G., Anaerobic ammonium oxidation discovered in a denitrifying fluidized bed reactor. FEMS Microbiology Ecology, 16(3), pp. 177-183, 1995.

[3] Thamdrup, B. \& Dalsgaard, T., Production of $\mathrm{N}<\mathrm{sub}>2</$ sub $>$ through Anaerobic Ammonium Oxidation Coupled to Nitrate Reduction in Marine Sediments. Applied and Environmental Microbiology, 68(3), pp. 1312-1318, 2002.

[4] Dalsgaard, T., Canfield, D.E., Petersen, J., Thamdrup, B. \& Acuna-Gonzalez, J., N2 production by the anammox reaction in the anoxic water column of Golfo Dulce, Costa Rica. Nature, 422(6932), pp. 606-608, 2003.

[5] Van de Graaf, A.A., de Bruijn, P., Robertson, L.A., Jetten, M.S. \& Kuenen, J.G., Autotrophic growth of anaerobic ammonium-oxidizing micro-organisms in a fluidized bed reactor. Microbiology, 142(8), pp. 2187-2196, 1996. 
[6] Third, K.A., Paxman, J., Schmid, M., Strous, M., Jetten, M.S.M. \& Cord-Ruwisch, R., Enrichment of anammox from activated sludge and its application in the CANON process. Microbial Ecology, 49(2), pp. 236-244, 2005.

[7] Holenda, B., Domokos, E., Rédey, Á. \& Fazakas, J., Dissolved oxygen control of the activated sludge wastewater treatment process using model predictive control. Computers \& Chemical Engineering, 32(6), pp. 1270-1278, 2008.

[8] Li, G., Carvajal-Arroyo, J.M., Sierra-Alvarez, R. \& Field, J.A., Mechanisms and Control of NO2-Inhibition of Anaerobic Ammonium Oxidation (Anammox). Water Environment Research, 89(4), pp. 330-336, 2017.

[9] Lu, X., Yin, Z., Sobotka, D., Wisniewski, K., Czerwionka, K., Xie, L., Zhou, Q. \& Makinia, J., Modeling the $\mathrm{pH}$ effects on nitrogen removal in the anammox-enriched granular sludge. Water Science and Technology, 75(2), pp. 378-386, 2017.

[10] Hu, Z., Lotti, T., van Loosdrecht, M. \& Kartal, B., Nitrogen removal with the anaerobic ammonium oxidation process. Biotechnology Letters, 35(8), pp. 1145-1154, 2013.

[11] Gonzalez-Martinez, A., Rodriguez-Sanchez, A., Garcia-Ruiz, M.J., Muñoz-Palazon, B., Cortes-Lorenzo, C., Osorio, F. \& Vahala, R., Performance and bacterial community dynamics of a CANON bioreactor acclimated from high to low operational temperatures. Chemical Engineering Journal, 287, pp. 557-567, 2016.

[12] Strous, M., Kuenen, J.G. \& Jetten, M.S.M., Key Physiology of Anaerobic Ammonium Oxidation. Applied and Environmental Microbiology, 65(7), pp. 3248-3250, 1999.

[13] Vives, J.C.M.T., López, H., Ganigué, R., Ruscalleda, M., Sànchez*, A., Vila, X., López, R., mjesús llorens, Salamero, M., González, E., Jiménez, E., Balaguer, M.D. \& Elorduy, M., Closing the Nitrogen Cycle from Urban Landfill Leachate by Biological Nitrogen Removal Over Nitrite and Thermal Treatment, 2003.

[14] Henze, M., Gujer, W., Mino, T. \& van Loosedrecht, M., Activated Sludge Models ASM1, ASM2, ASM2d and ASM3. IWA Publishing, 2006.

[15] Rustum, R., Modelling Activated Sludge Wastewater Treatment Plants Using Artificial Intelligence Techniques (Fuzzy Logic and Neural Networks). In Heriot-Watt University, 2009.

[16] Xie, B., Ma, Y.W., Wan, J.Q., Wang, Y., Yan, Z.C., Liu, L. \& Guan, Z.Y., Modeling and multi-objective optimization for ANAMMOX process under COD disturbance using hybrid intelligent algorithm. Environmental Science and Pollution Research, 25(21), pp. 20956-20967, 2018.

[17] Dochain, D. \& Pauss, A., On-line estimation of microbial specific growth-rates: An illustrative case study. The Canadian Journal of Chemical Engineering, 66(4), pp. 626-631, 1988.

[18] Hong, S.H., Lee, M.W., Lee, D.S. \& Park, J.M., Monitoring of sequencing batch reactor for nitrogen and phosphorus removal using neural networks. Biochemical Engineering Journal, 35(3), pp. 365-370, 2007.

[19] W.H. Organization, Sustanable Development Goal 6, In United Nation, 2018.

[20] W.H. Organization, Sustainable Development Goal 7, In 2018. 